\title{
Biografia: quando o indivíduo encontra a história
}

Mary Del Priore

\begin{abstract}
A ciência histórica nos deixa na incerteza sobre os individuos. Ela só nos revela os pontos pelos quais eles se ligaram às açôes gerais. Ela nos diz que Napoleão sofria no dia de Waterloo, que é preciso atribuir a excessiva atividade intelectual de Newton à continência absoluta de seu temperamento, que Alexandre estava bêbado quando matou Clitos e que a fistula de Luis XIV pode ser a causa de algumas de suas resoluçôes. Todos esses fatos individuais só têm valor porque modificaram os acontecimentos ou porque poderiam ter desviado a série. São causas reais ou possiveis. É preciso deixá-las aos sábios.

Marcel Schwob, Vidas Imaginárias.
\end{abstract}

A biografia, uma das primeiras formas de história - depois das dos deuses e de homens célebres -, retém cada vez mais a atenção dos historiadores. Todavia, a moda da biografia histórica é recente. Com efeito, até a metade do século XX, sem ser de todo abandonada, ela era vista como um gênero velhusco, convencional e ultrapassado por uma geração devotada a abordagens quantitativas e economicistas.

Exemplo disso é um artigo de Marc Ferro, datado de abril de 1989, em que o grande biógrafo e historiador francês chama a biografia de "o aleijão" da história - le handicapée de l'Histoire. Ferro debitava esse desinteresse a duas matrizes: a da valorização do papel das massas - sans-culottes, camponeses e operários, e a diminuição do papel dos "heróis" inspirada no determinismo ou no funcionalismo, das análises marxistas e estruturalistas que marcaram a produção europeia dos anos $60{ }^{1}$

Mas vamos olhar um pouco mais para trás, para entender a genealogia desta que Littré definiu como "uma espécie de história que tem por objeto a vida de uma única pessoa". A biografia mudou ao longo dos tempos. No início era o verbo e o verbo, a narrativa. E a narrativa era história em Heródoto, mas, também, retórica, em Tucídides. Em um quanto em outro, a preocupação com o efeito literário era maior do que com a exatidão das informações. Tucídides, por exemplo, recheou de discursos fictícios sua história da guerra do Peloponeso, que queria imorredoura, ktêma es aiei. Ele deu a palavra a seus atores a fim de que eles exprimissem análises sobre suas próprias açôes.

O modelo grego inspirou profundamente os historiadores romanos: Tito Lívio, do seu lado, encheu seus textos com discursos imaginários para destacar a psicologia de personagens evocados. Da mesma forma, Tácito pintou os imperadores do primeiro século, tentando penetrar sua mentalidade. Todos esses historiadores pertencem à história das literaturas grega e latina. Por quê? Pois seu esforço de elucidação e interpretação dos fatos não obstruiu jamais o desenvolvimento da narrativa. $O$ discurso, nesses casos, não tinha função de prova explicativa. Era, sim, um procedimento retórico ligado a um acontecimento histórico mais amplo.

A seguir, a hagiografia encarregou-se de demonstrar a exemplaridade humana. A vida dos santos deveria incentivar modelos aos leitores. As encarnações do sagrado se tornavam modelares no percurso realizado por mártires, doutores e confessores. A partir dos séculos XII e XIII, os santos deixaram o mundo fechado dos monastérios. A santidade passou a ser imitada no cotidiano e a narrativa sobre a vida de cavaleiros invadiu a Idade Média. Era o início de um período de heróis. Heróis, ao mesmo tempo, objetos de transferência do sagrado, atores de intrigas e portadores de valores positivos.

Com o Renascimento emergiu uma nova maneira de viver e de conceber o destino do homem no mundo. $\mathrm{O}$ indivíduo começou a se liberar de tutelas tradicionais que pesavam sobre o seu destino. Ele ousou dizer "eu". Na pintura, sobretudo no Norte da Europa, retratos pintados por Van Eick, Roger van de Vries e Dürer, entre outros, confirmaram a valorização de sua existência. O mundo social mudou de núcleo de gravidade. Das leis superiores impostas por Deus, pelo Estado ou a família, tal centro voltou-se para o culto de si. O indivíduo tornou-se meta e norma de todas as coisas. ${ }^{2}$ 
Nos séculos seguintes, o individualismo não cessou de se afirmar. Por isso mesmo, "escrever sua vida" tornou-se moda: Marguerite de Valois, Commynes, Monluc, Retz, Saint-Simon entre outros memorialistas do Antigo Regime, construíam a memória do mundo e a memória de i. $^{3}$ No século XVIII, o herói medieval foi substituído pelos grands hommes dos quais Voltaire diria: "São aqueles que se destacaram no útil ou no agradável." Contrariamente ao herói, o "grande homem" tinha que ter uma função: ser proveitoso à sociedade. Uma das formas de contar seus feitos, ou estudá-lo, era a biografia. Biografia, palavra que, dicionarizada em 1721, designava um gênero que tinha por objeto a vida dos indivíduos. Antes, as biografias apareciam na forma de "memórias", ou seja, relações escritas nas quais o indivíduo narrava fatos dos quais participara ou fora testemunho.

No século XIX, as biografias tiveram importante papel na construção da ideia de "nação", imortalizando heróis e monarcas, ajudando a consolidar um patrimônio de símbolos feito de ancestrais fundadores, monumentos, lugares de memória, tradiçōes populares etc. Esta concepção foi retomada pela corrente positivista. A biografia assimilou-se à exaltação das glórias nacionais, no cenário de uma história que embelezava o acontecimento, o fato. Foi a época de ouro de historiadores renomados como Taine, Fustel de Coulanges e Michelet, autor de excepcionais retratos de Danton a Napoleão.

Pouco a pouco, na mesma época, história e literatura se divorciaram. A história tornou-se uma disciplina e monopólio de acadêmicos. Primeiro, sob as bordoadas dos positivistas da Neue Historishe Schule de Leopold Von Ranke, cujas repercussōes logo se fizeram sentir entre belgas e franceses. A seguir, e de maneira decisiva sob a influência irradiadora da Escola dos Annales, animada por Lucien Fébvre e Marc Bloch, no início do século XX. Foi o momento do eclipse da narrativa, enterrado junto com a história factual. Ao minimizar a história política, diplomática, militar ou eclesiástica que evidenciava o indivíduo e o fato, a Nova História, nascida dos Annales nos anos 60, optou por privilegiar o "fato social total" em todas as suas dimensões econômicas, sociais, culturais e espirituais.

Como bem observou Paul Ricoeur, "à noção de fato, concebido como salto no tempo, eles opuseram aquela de tempo social cujas categorias maiores - conjuntura, estrutura, ciclo, crescimento, crise etc. - foram emprestadas à economia, à demografia e à sociologia.”4 Marx aterrissava em meio aos estudos históricos.

Vale sublinhar que a Escola dos Annales renovou de alto a baixo os métodos de trabalho do historiador, fazendo desse um especialista escrevendo para outros especialistas. No que deveria ser uma ciência, não havia espaço para a arte. Menos espaço ainda, pois a nova orientação excluía a biografia, que é narrativa por excelência.

Talvez não tenha sido um acaso o fato de, na primeira metade do século, escritores como Stefan Zweig investirem com entusiasmo nas biografias históricas - Maria-Antonieta, Fouché, Erasmo - usando os mesmos princípios do historiador romântico Michelet, ou seja, a preocupação em recuperar "a vida total", o "drama da vida". ${ }^{5}$ O ficcionista tão desprezado em sua época pelos "especialistas" escreveu um pequeno livro sobre os bastidores da história chamado de Sternstunden der Menschheit. Suas miniaturas iluminaram a história documental com páthos humano. E ainda, deve-se à sua intuição (é nome feio?), pelo menos em parte, o ressurgimento do poeta Hölderlin, depois de uma longa noite em que foi ignorado pelos "especialistas". E quem seria Nietzsche sem Hölderlin?

Enquanto os historiadores preferiram rejeitar os ídolos individuais e os recortes cronológicos dados pelo tempo de uma existência, escritores se tornaram, então, os grandes biógrafos: Guy de Pourtalés. Gide, Michel de Leiris, André Maurois, no mundo literário francês. Lytton Strachey e Antonia Fraser, no anglo-saxão, entre outros. Convite à viagem artificial no passado, fortemente ligada aos fatos, a maior parte das biografias era acrítica e lançava suas raízes no terreno das paixōes coletivas. Elas correspondiam a um público ávido de fatos históricos, de acontecimentos sensacionais ou de enigmas insolúveis: na França, por exemplo, o caso do Colar da Rainha ou a desaparição do tesouro dos templários. A paixão pela biografia crescia e fez nascer o romance genealógico de Claude Simon e Georges Perec. Ou ainda a autobiografia psíquica de um Hermann Broch. ${ }^{6}$ Havia sede desse gênero, notadamente no mundo europeu e anglo-saxão. 
Historiadores começaram, contudo, a operar um discreto retorno à biografia. Lucien Febvre, um dos fundadores da revista Annales, foi pioneiro em colocar as bases de uma biografia histórica renovada: "Os homens, únicos objetos da história [...] sempre capturados no quadro das sociedades a que pertencem." Instaurava-se uma "biografia modal" que, debruçada sobre o indivíduo, informava sobre a coletividade. Ao fazer as biografias de Lutero ${ }^{7}$ e Rabelais, ${ }^{8}$ Lucien Febvre deu vida a personagens tributários de uma utensilagem mental que os ultrapassava e os permitia se situar numa dada época e sociedade. Estavam lançadas as pistas que levariam do indivíduo ao ator ou atores da história. ${ }^{?}$

Consequência da emergência da nova História Social e da influência marxista, os meados do século XX continuaram a manter a história biográfica em segundo plano. Esta abordagem era marcada pelo diálogo estreito com outras Ciências Humanas e pela ênfase de Fernand Braudel na história total. Coube a ele sublinhar as relações entre o homem, a geografia (no livro o mar Mediterrâneo, e não o rei Felipe IV, é o protagonista principal) e as condiçôes materiais de vida, numa visão totalizante e socioeconômica da história. A abordagem conhecida como Nova História recusava as análises que só retinham um único fator em detrimento da multiplicidade de componentes particulares, das circunstâncias que levavam a uma conjuntura. Mas junto com os documentos, Braudel não conseguiu ignorar o páthos: "Nesse livro, os barcos navegam; as ondas repetem sua canção; os vinhateiros descem das colinas. [...]". Não é poesia?

Foi, contudo, preciso esperar os anos 70 e 80 para assistir ao fim da rejeição à biografia histórica. $\mathrm{O}$ epistemólogo François Dosse anunciou, então, a chegada de uma "idade hermenêutica" na qual o objetivo seria capturar "a unidade pelo singular". Até que enfim, o indivíduo encontrava a história. O fenecimento das análises marxistas e deterministas, que engessaram por décadas a produção historiográfica, permitiu dar espaço aos atores e suas contingências novamente. Foi uma verdadeira mudança de paradigmas. A explicação histórica cessava de se interessar pelas estruturas, para centrar suas análises sobre os indivíduos, suas paixões, constrangimentos e representações que pesavam sobre suas condutas. $\mathrm{O}$ indivíduo e suas ações situavam-se em sua relação com o ambiente social ou psicológico, sua educação, experiência profissional etc. O historiador deveria focar naquilo que os condicionava a fim de fazer reviver um mundo perdido e longínquo. Esta história "vista de baixo" dava as costas à história dos grandes homens, motores das decisões, analisadas de acordo com suas consequências e resultados, como a que se fazia no século XIX. ${ }^{10}$

Mas a possibilidade de colocar a biografia em questão ganhou espaço com um amplo debate entre historiadores e sociólogos, no meio dos 1980 . O polêmico texto "L'illusion biographique", de Pierre Bourdieu, criticava a subjetividade de biografias históricas, segundo ele, capazes exclusivamente de reconstruir a vida de forma artificial, mesmo "absurda": "11 "A história de vida é uma dessas noções do senso comum que entraram, de contrabando, no universo erudito", ${ }^{12}$ fustigava o famoso sociólogo.

A crítica da biografia por este que era considerado um dos maiores intelectuais do mundo, longe de afastar o interesse de historiadores, os desafiou. Convidou-os a pensar a biografia de um ângulo novo. Assistiu-se, assim, a uma volta do gênero, mas de uma biografia que nada tinha a ver com um retorno à história heroica e literária dos grandes homens. Enterrava-se a biografia positivista dos tempos de antanho, descrita por Jacques Le Goff como "tradicional, superficial, anedótica, cronológica, sacrificada a uma psicologia ultrapassada e incapaz".

A reabilitação da biografia histórica integrou as aquisições da história social e cultural, oferecendo aos diferentes atores históricos uma importância diferenciada, distinta, individual. Mas não se tratava mais de fazer, simplesmente, a história dos grandes nomes, em formato hagiográfico - quase uma vida de santo -, sem problemas, nem máculas. Mas de examinar os atores (ou o ator) célebres ou não, como testemunhas, como reflexos, como reveladores de uma época. A biografia não era mais a de um indivíduo isolado, mas, a história de uma época vista através de um indivíduo ou de um grupo de indivíduos. Ele ou eles não eram mais apresentados como heróis, na encruzilhada de fatos, mas como uma espécie de receptáculo de correntes de pensamento e de movimentos que a narrativa de suas vidas torna mais palpáveis, deixando mais tangível a significação histórica geral de uma vida individual. ${ }^{13}$ 
Segundo Marc Ferro, a biografia deve ainda aos estudos sobre a vida privada dos indivíduos, estudos que permitiram dessacralizar, segundo ele, os papéis estritamente públicos que esses exerceram, revelando as complexas relaçôes entre vida privada e vida pública.

Segundo Le Goff, a introdução do gênero biográfico na história atual é um instrumento útil e suplementar usado pela História Cultural. É uma maneira "de continuar a fazer história por outros meios", como explicou o historiador reiteradas vezes quando interpelado sobre suas pesquisas para os estudos de São Francisco de Assis e depois, de São Luiz Rei de França. ${ }^{14}$ No primeiro, o medievalista relacionou a vida do poverello com a urbanização e o enriquecimento das cidades-Estado italianas. No segundo, problematizou a narrativa, perguntando-se "São Luiz existiu?". A resposta foi original: trabalhando com as várias imagens que se sobrepõem a um mesmo indivíduo, demonstrou que uma biografia pode conter várias outras. Enfim, uma vida pode contar outras tantas.

Le Goff é o melhor exemplo do que propunham os historiadores franceses ao reinventar a biografia. $\mathrm{Na}$ tradição do espírito dos Annales, ela deve se instaurar por uma "questão" e se formular como um caso de "história-problema". Como toda narrativa de vida, ela precisa se submeter a uma cronologia de fatos, mas, contrariamente, à vida - ao destino -, é "uma construção feita de acasos, hesitações e escolhas" que permitem ao biógrafo, segundo Le Goff, escapar à tal ilusão biográfica fustigada por Bourdieu.

Enquanto, algumas décadas antes, Fernand Braudel preconizava a existência da "longa duração" em toda a análise histórica, Le Goff rompeu com esta tradição, insistindo sobre a vida individual como "duração significativa para a história". Ele convidou mais geralmente a buscar "durações pertinentes em história", "que permitiram, não só a observar um fenômeno", mas também ver "uma grande parte da evolução histórica”. Segundo ele, a vida humana é um excelente exemplo em história de vida e a de São Luiz, em particular, permitia medir uma série de fenômenos. Esta abordagem apresentou o interesse de ultrapassar a oposição entre história narrativa e história estruturalista, ou seja, incentivou a encontrar as estruturas por outro recorte. Segundo o mesmo autor, "quase em ação e em encarnação", longe das frias estruturas propostas por Braudel.

A biografia desfez também a falsa oposição entre indivíduo e sociedade. $\mathrm{O}$ indivíduo não existe só. Ele só existe "numa rede de relações sociais diversificadas". $\mathrm{Na}$ vida de um indivíduo, convergem fatos e forças sociais, assim como o indivíduo, suas ideias, representações e imaginário convergem para o contexto social ao qual ele pertence. No seu estudo sobre os marranos no Nordeste do Brasil, Nathan Wachtel, por exemplo, demonstrou por meio de uma "enquete de micro-história", que cada indivíduo estudado é situado numa trajetória dada, assim como "na sua relação com os outros no seio de uma sociedade global". "Os indivíduos - diz - representam mais do que eles mesmos e cada qual, a seu modo, exprime algo do coletivo do qual não podem se abstrair."

A biografia permitiu então a abordagem histórica pelo foco num indivíduo que não é necessariamente ilustre ou conhecido, exatamente porque ele não é ilustre ou conhecido. É Wachtel que à maneira de seus colegas reitera que isto é possível, pois os destinos individuais estão situados em diversas redes que se cruzam: a casa e a família, o espaço regional, o universo espiritual, a utensilagem mental de uma época. "O singular se abre para o geral, na medida em que é recuperado em sua inesgotável riqueza." 15 Obras que também marcaram este debate foram: Moi, Pierre Riviére, história do matricida francês que também matou os irmãos, sob a pena de Michel Foucault ${ }^{16}$ ou o estudo de Georges Duby sobre Joana D'Arc. ${ }^{17}$

A discussão historiográfica entre os herdeiros ou a segunda geração dos Annales abriu outra frente de trabalho. Desta vez, influenciado pela produção italiana dos anos 80 . Nascia, nesta época, uma coleção da editora Einaudi, dirigida por Carlo Guinzburg e Giovanni Levi intitulada Microestorie. Ao longo da década, a editora e as obras aí publicadas ajudaram a consolidar os conceitos desta que passou a ser uma abordagem: a Micro-História. Assumindo a legitimidade do "fatiamento da história" posto em cena pela Nova História, porém preocupada com a problematização mais nítida do objeto de investigação, especialmente quanto às hierarquias e conflitos sociais, a Micro-História trouxe à luz importantes biografias extraídas desta nova prática historiográfica. 
Alguns enredos ilustrativos deste tipo de narrativa seriam o clássico O queijo e os vermes, de Carlo Guinzburg, cujo personagem é um moleiro friulano, Domenico Scandella, conhecido por Mennochio; a história de $O$ retorno de Martin Guerre, de Natalie Davis, a trajetória de um impostor que se faz passar por marido de uma camponesa do sul da França; Benedetta, a visonária lésbica do livro de Judith Brown, Atos Impuros, ou o exorcista Giovan Battista Chiesa, ator de $A$ herança Imaterial, escrita por Giovanni Levi.

Nestas quatro obras salta aos olhos algumas das características que, de fato, distinguem a Micro-História da História da Cultura ou das Mentalidades: a ênfase nos conflitos de classe, a despreocupação com os contextos amplos e a longa duração, a renúncia à história totalizante, cara aos franceses contemporâneos de Braudel, nos anos sessenta. No mais, como em outras biografias sob o guarda-chuva dos Annales, todos os temas cabem nestas monografias, sobretudo, pois ambas as abordagens - A História Cultural e a Micro-História - se preocupam com os anônimos da história, o "popular", os "de baixo". Ambas as abordagens diminuem o foco da história, concentrando-se no tempo significativo de fatos, açôes e representações que cercam o indivíduo. A diferença? Oriundos da tradição marxista, os autores ligados à Micro-História se preocupam com conflitos de classe sub-reptícios aos fatos e personagens históricos.

O que vale sublinhar é que as biografias caíram como uma luva para resolver alguns problemas práticos dos historiadores. Tomemos, por exemplo, a contradição entre ideias, representações e práticas sociais que fizeram historiadores americanos criarem a "história das ideias", distinta, daquela das práticas. Os autores franceses e italianos demonstraram que as primeiras não são mais um fato em si, motivo ou causa de eventos históricos, mas "modos de representação" de um momento histórico. Trata-se, portanto, de achar um equilíbrio entre o indivíduo ou o personagem, seu livre-arbítrio, suas intençõos pessoais e a escala mais ampla de convençôes culturais e "mentalidades coletivas" nas quais ele está imerso. ${ }^{18}$

Abordagem perfeita - se perguntariam alguns? A princípio, não. Pois que, por definição, a biografia é centrada num indivíduo, ela coloca o problema da "representatividade" deste mesmo ator histórico. Mas com o desenvolvimento da história cultural, as abordagens se concentraram nos laços que ligavam o indivíduo à cultura, no sentido mais amplo do termo. Num artigo que fez a volta ao mundo David Brion Davies se perguntava, justamente, como achar "os pontos de intersecção" entre um indivíduo e o quadro social, cultural e político do qual participa. Segundo o historiador americano, bem como o francês Le Goff, a biografia individual ou coletiva (no caso de estudos de família ou prosopografias) oferece uma solução metodológica a esta pergunta, pois ela implica o estudo de um indivíduo ou de grupo de indivíduos que representam uma classe social, uma profissão, uma fé ou crença, desde que se defina, previamente, a estrutura social a que pertencem. Pode-se igualmente examinar a maneira pela quais as crises pessoais de um indivíduo complexo refletem as tensões de uma época, e como as soluções pessoais do conflito fazem eco, se apropriam ou se impregnam às transformaçōes de uma cultura.

Assim, o indivíduo é, ao mesmo tempo, ator crítico e produto de sua época, seu percurso iluminando a história por dois ângulos distintos. Um explícito, pela iniciativa voluntária do observador que propõe uma análise da sociedade na qual o personagem está inscrito. O outro, implícito, avaliado no percurso do personagem que ilustra, por sua vez, as tensões, conflitos e contradições de um tempo, todos essenciais para a compreensão do período. Neste caso, o indivíduo encarna, ele mesmo, tais tensōes. ${ }^{19}$

E quanto à escrita das biografias? Graças ao gênero, o historiador se tornou um escritor que se dirige a um público que aguarda uma narrativa de acontecimentos encadeados e uma intriga codificada por fatos reais, interpretados. Ao fim das contas, a estrutura da biografia se distingue daquela do romance por uma característica essencial: os eventos contados pela narrativa do historiador são impostos por documentos e não nascidos da imaginação. A história, afirmou peremptoriamente Paul Veyne, nada mais é do que "uma narrativa verídica". ${ }^{20}$

De fato, o historiador reconstitui - a palavra é significativa - as coisas do passado. Mas ao fazê-lo, ele tenta imaginá-las como se as tivesse visto. Há aí um cruzamento perigoso, mas real, com a imaginação literária. Por outro lado, muitas vezes o romancista não se esquiva de misturar personagens históri- 
cos e fatos com data reconhecida aos personagens fictícios e eventos idealizados. Um caso emblemático é o de Marguerite Youcenar com sua Obra em negro ou Memórias de Adriano. ${ }^{21}$

O discurso exposto pelo biógrafo ou pelo romancista tem em comum a mise em intrigue da narrativa. Todavia, a intriga do biógrafo deve se conformar a determinadas leis de encadeamento e aos cânones da disciplina, às quais escapa o romancista. Na narrativa de ficção todas as distorções são permitidas. $\mathrm{O}$ tempo pode ser desdobrado entre o tempo das coisas contadas e o tempo que se leva para contá-las. Essa é uma via que o historiador não pode jamais trilhar.

É lógico que o historiador, seja ele biógrafo ou não, se confronta mais do que o romancista com duas questões que tomam a forma do "por que" e do "como". E é precisamente neste momento que o historiador deve integrar em sua narrativa a análise das realidades de ordem coletiva, tais como as forças sociais, a situação econômica, as pulsões culturais e religiosas, as mentalidades e até o clima. As preocupações mais emblemáticas da Escola dos Annales seguem presentes ainda hoje. ${ }^{22}$

Voltando à escrita da biografia, não se tornou frequente dizer que um bom livro de história - como os que escreve, por exemplo, o jornalista Eduardo Bueno - se lê como romance, escapando ao tédio que inspiram os livros universitários? E nesta fórmula elogiosa, o como - sublinhe-se - é fundamental. O livro é, então, recomendado. Trata-se de história garantida. De fatos acontecidos, de um fenômeno histórico explicado, de arquivos e documentos inéditos que foram examinados, de conhecimentos novos descobertos. Não obstante, o livro se lê: a montagem, a intriga, a escrita fazem com que os leitores o penetrem como numa obra de ficção. Ou seja, o livro convida o leitor a se deixar arrastar pelo prazer da leitura; ele instrui enquanto diverte. Embora tudo faça para parecer um romance, o livro em questão não é um romance histórico - gênero no qual o essencial se subordina ao acessório. E, por fim, é graças a este como que o leitor ganha nas duas frentes: a da história e a da literatura.

Mas, afinal, a história conta uma história? Há 40 anos atrás a resposta seria: não! Os historiadores profissionais invocariam o compromisso que assumiram no século XIX de fazer valer a ciência contra a arte. E ciência de observação, ciência de análise, ciência leitora e intérprete de documentos que um dia desembocariam em sínteses, por que não, em leis, ou, ainda na suprema verdade? A narrativa? Uma ingenuidade. A coisa, contudo, mudou. Em 1979, um historiador inglês, Lawrence Stone, levantou a lebre tomando suas distâncias da história científica, ou "da velha história" como ele a denominou, até então, prevalente. ${ }^{23}$ Muito se tentou fazer uma história não ritmada pela narrativa, mas, pela interpretação de séries, ciclos, repetições. O grande Fernand Braudel chegou a dizer que os historiadores não contavam. Eles apenas explicavam. Na realidade, por meio de hipóteses, eles observavam continuidades a partir das quais construíam fatos. ${ }^{24}$

Mas seria isto possível? No seu mais importante livro, O Mediterrâneo e o mundo mediterrâneo no tempo de Felipe II, o próprio Braudel não teria transformado o declínio deste mar intenso e fechado numa espécie de herói coletivo na cena mundial ${ }^{25} \mathrm{O}$ certo é que não há como fazer diferente. Não é possível relatar e analisar uma situação social e econômica de um período passado sem a ajuda da narrativa. Ou seja, sem colocar em relação (é o que os franceses chamam de míse em intrigue) os elementos de natureza diferente, sem fazer intervir diferentes personagens, os chamados atores históricos, notórios ou anônimos. Qualquer que seja a vontade do autor de fazer uma escrita impessoal, com a não utilização deliberada do "eu", com a recusa de colocar em primeiro plano tal batalha ou tal nome célebre, o fato é que para que as obras sejam legíveis e coerentes, não se pode eliminar a estrutura narrativa.

E a propósito da importância da narrativa, bem disse Paul Veyne, especialista em epistemologia quando lançou: "A história é a narrativa de fatos, o resto decorre dela" ${ }^{26}$ Ele denominou "intriga" a possibilidade do método de reconstituição do historiador assemelhar-se ao do romancista ou do autor de romances policiais. Observe-se, aliás, que o gosto pela escritura e mesmo pelo "estilo" marcou a produção da historiografia francesa nos últimos 30 anos.

No céu dos historiadores, os anos 80 se fecharam sob o signo do "tempo das incertezas", para retomar a expressão usada no editorial da revista Annales. ${ }^{27}$ A natureza do discurso histórico era, então, ob- 
jeto de trabalhos que detonavam as posiçôes tradicionais entre os profissionais da Nouvelle histoire. $\mathrm{Na}$ esteira da crítica feita por Michel Foucault, ${ }^{28}$ Michel de Certeau, ${ }^{29}$ e, sobretudo, Paul Ricoeur os historiadores foram obrigados a reconhecer que o discurso é sempre narrativa no sentido de "colocar em ação as açōes representadas". A história, na sua escrita, não pode se subtrair aos procedimentos literários. E isto não é um simples caso de retórica, mas, ao contrário, trata-se da validade e da legitimidade do discurso histórico. Redigir é etapa crucial do trabalho científico e maneira eficiente de avaliar as ambiçôes da disciplina. Paul Ricoeur demonstrou impiedosamente que toda a história, inclusive a serial e quantitativa, ainda que à revelia, é sempre construída pelas formas que governam a narrativa.

O que fazer, então, da pretensão científica e do sonho de objetividade, se a produção do historiador se assemelha a uma narrativa de ficção? Os americanos responderam primeiro. $\mathrm{O}$ movimento conhecido como Linguistic Turn marcou uma radicalização nas reflexōes em andamento na Europa. Agrupando várias escolas de historiadores e de especialistas em ciências sociais, este movimento, que, aliás, não possui unidade teórica, proclama que toda realidade social, passada ou presente, se reduz a um jogo de linguagem, a uma construção discursiva. Ao fim e ao cabo, a história não passaria de um simples "gênero" literário, perdendo toda a ambição de ser um discurso de verdade. ${ }^{30}$ Deste ponto de vista, a história não poderia ser mais do que "a form of fiction-making operation", incapaz de estabelecer um conhecimento científico do passado, incapaz, também, de reconhecer falsificaçôes e falsários. É óbvio que a Europa, teatro das maiores atrocidades do século XX, reagiu. Este relativismo absoluto leva a vias perigosas. E elas foram rapidamente usadas por historiadores revisionistas e negacionistas, quando se tratou de dizer, por exemplo, que não houve Holocausto de judeus, ciganos e homossexuais durante a Segunda Grande Guerra.

E é na direção de Paul Ricoeur que nos voltamos para aprender as delicadas relações entre história e verdade.

O historiador não é um simples narrador: ele dá razões para explicar sua escolha de tal e qual fator em detrimento de outro, quando se trata de um fato histórico. O poeta cria uma intriga que se basta por seu esqueleto causal. Mas ele não é feito de argumentação.

\section{E Roger Chartier crava:}

É preciso lembrar que o foco do conhecimento é constitutivo da intencionalidade histórica. Ele funda estas operações específicas da disciplina: construção e tratamento de dados, critérios de verificação de resultados, validação da adequação entre o discurso do saber e seu objeto. ${ }^{31}$

Mas enquanto na França, Alemanha e Estados Unidos o discurso do historiador e seus paradigmas estão no coração das polêmicas, ${ }^{32}$ abaixo do Equador, não só o discurso, mas, também, o papel do historiador ainda está em discussão. Sim. Porque a história, antes de ser uma disciplina, é uma prática social. O que quer dizer que homens e mulheres que se dizem historiadores fazem história para um público que os lê ou escuta. Seu reconhecimento social, assim como seus salários, dependem da sociedade que lhe acorda um status e lhe assegura uma remuneração. O duplo reconhecimento, o dos pares e o do público, consagra o historiador como tal. E mais, a história não é uma disciplina, monolítica; mas ela é composta por diferentes grupos que rivalizam na tarefa de, mediante um programa, prescrever o objeto da pesquisa e a maneira correta de apresentá-la, portanto, de narrá-la.

O que é curioso é que, contrariamente ao que lhes acontece na Europa, aqui os historiadores têm pouca visibilidade em comparação com os jornalistas. Mas a história vem se tornando uma mania. Ela está em toda a parte. De repente, "tudo é história", parodiando o grito do consagrado Jacques Le Goff quando ampliou a constelação de documentos que pode usar o historiador. Tudo tem história. No Brasil vimos surgir, nos últimos dez anos, um público que lê e gosta de história. Revistas de divulgação se multiplicaram, algumas delas atingindo um total aproximado de 300.000 leitores por mês. ${ }^{33}$ Outros produtores culturais tais como documentaristas, cineastas, produtores de conteúdos para sites, procuram, cada vez, mais desenvolver projetos nos quais a informação tenha raízes históricas. Um domínio 
inteiramente novo, o da educação patrimonial associado ao turismo cultural, potencializou, ilimitadamente, o papel de historiadores regionais e dos institutos de história, antes invisíveis porque às margens dos grandes circuitos. Os museus regionais também se multiplicaram, valorizando a autoestima de populaçôes antes nas sombras da metrópole mais próxima. Os movimentos afirmativos deram valor, também, não só a cultura indígena ou afrodescendente como um todo, mas seus desdobramentos localizados nas múltiplas manifestações de cultura material e imaterial - quilombos, festas e tradições - que variam de região a região. Isto quer dizer que, muito além dos jardins da universidade, existem, hoje, centenas de dezenas de consumidores de história. Consumidores, contudo, a quem a discussão sobre se a história está entre ficção ou ciência pouco importa.

Para estes consumidores de história, o discurso histórico não difere muito do literário. As relações entre as duas disciplinas não são nem hierárquicas, nem diretas. Ou seja, no seu significante o texto de história é um produto, submetido às condições sociais, culturais e econômicas de sua produção. $\mathrm{O}$ autor, por sua vez, lhe dá o "sopro gerador" enquanto o leitor o ressignifica. ${ }^{34}$ Com a diferença que o sopro gerador que lhe insufla o historiador passa por uma série de regras do ofício: a pesquisa documental, a crítica interna e externa da documentação, a interpretação das informações trazidas pelas fontes, o diálogo com os especialistas do assunto, a inclusão de notas e referências, e, finalmente, o preenchimento de uma lacuna. Ou seja, como a literatura, a história é, também, um processo vivo de produção, circulação e consumo de discursos. ${ }^{35}$ Como o romance, a história conta. E contando, ela explica. Como o romance, a história escolhe, seleciona, simplifica, organiza, reduz um século a uma página. A diferença, sublinharia Paul Veyne, é que "a história é um romance; mas um romance de verdade" [...] e os historiadores contam eventos verdadeiros que têm o homem por ator". ${ }^{36}$

A partir desta constatação, historiadores brasileiros terão que repensar que tipos de texto produzirão e entre eles, qual seria o papel da biografia histórica, tão eficiente para dar a conhecer o passado. Agora, não mais para atender exclusivamente às exigências herméticas da Academia, mas, também para responder a uma exigência ou demanda social. Há milhares de leitores para um tal produto cultural. Não há nada de anedótico nesta iniciativa, se ela for realizada no cumprimento das exigências da profissão. Se ninguém contesta o talento de tantos romancistas e jornalistas que se aventuraram a escrever biografias históricas, por que recusar a pertença ao domínio literário aos biógrafos que são historiadores de formaçãa?

Já ensinava Pierre Goubert, ao escrever uma das obras mais importantes da historiografia francesa: "Quero escrever um livro para meus amigos e netos lerem sem irritação, nem tédio." E o antídoto contra o tédio seria a capacidade de produzir textos que "dão a ver". Textos que reencontrem o tempo perdido, que chamem à cena os fantasmas da história, que tenham capacidade de conversar com os mortos. Que permitam a magia de entrar na vida de outrem e que façam dos historiadores, caçadores de almas capazes de encantar os leitores graças às biografias históricas.

\section{Notas}

${ }^{1}$ La biographie, cette handicapée del'histoire, in Magazine Litteraire, no 264, avril, 1987, p. 85-86.

${ }^{2}$ Vários autores trataram deste momento charneira na história ocidental. Vejam-se, por exemplo, Norbert Elias, La société des individus, Paris, Fayard, 1991, Michel Foucault, Le souci de soi, terceiro volume de Histoire de la Sexualité, Paris Gallimard, 1987, Charles Taylor, Sources du moi. La formation de l'identité moderne, Paris, Cerf, 1979, Tzvetan Todorov, Éloge de l'individu - Essai sur la peinture flamande de la Rennaissance, Bruxelas, Adam Biro, 2001, Jean-Claude Kaufmann, Ego. Pour une sociologie de l'individu, Paris, Nathan, 2001.

${ }^{3}$ Sobre o tema ver Frédéric Briot, Usage du monde, usage de soi - Enquêtes sur les mémorialistes d'Ancien Regime, Paris, Seuil, 1994. Marc Fumaroli, "Les Mémoires du XVIIe siècle au Carrefour desGenres en Prose”, XVII Siècle, 1971, nºs 94-95. Georges Gusdorf, Lignes de vie 1 Les écritues du moi e Lignes de vie 2, Auto-bio-graphie, Paris Odile Jacob, 1991.

${ }^{4}$ Paul Ricoeur, Temps et Récit, t. I, Paris, 1983, p. 147.

${ }^{5}$ Em entrevista à revista Nouvelles Litteraires, Zweig dizia que, para ele, a literatura "era um meio de exaltação da existência, um meio de tornar mais claro e inteligível o drama da vida". 
${ }^{6}$ Sobre as autobiografias do século XX, ver Claire de Ribaupierre, Le roman généalogique - Claude Simon et Georges Perec, Bruxelles, Editions de la Part de l'oeil, 2002 e Dominique Viard (org.), Paradoxes du biographique, Revue des Sciences Humaines, no 263, 2002. O clássico livro de Jean Starobinski, La transparence et l'obstacle, analisa do ponto de vista da história da literatura as relações entre Rousseau e suas memórias como uma autobiografia.

${ }^{7}$ Un destin, Martin Luther, Paris, PUF, 1928, reedição 1988.

${ }^{8}$ Le problème de l'incroyance au XVIIe siècle. La religion de Rabelais, Paris, Albin Michel, 1942.

${ }^{9}$ Ver seu Combats pour l'Histoire, Paris, Armand Collin, 1953.

${ }^{10}$ Ver seu excelente Le pari biographique. Écrire une vie, Paris, La Découverte, 2005.

${ }^{11}$ Pierre Bourdieu, in "L'illusion biographique", Actes de la Recherche en Sciences sociales, 62-63, juin 1986, investe contra a subjetividade das biografias e em favor das várias histórias possíveis de vida para cada agente social. Mas o autor ignora a crítica de excessiva objetividade.

${ }^{12}$ In Actes RSS, no 62/63, "L’Ilusion Biographique”, p. 69-72.

${ }^{13}$ Le Goff, Jacques “Comment écrire une biographie historique aujourd hui”, Le Débat 54 (1989) 48-53.

${ }^{14}$ Le Goff, Jacques, Saint Louis, Paris, Gallimard, 1996.

15 Wachtel, Nathan, La foi du souvenir: labyrinthes marranes, Paris, Seuil, 2001.

${ }^{16}$ Foucault Michel, Moi, Pierre Riviére ayant égorgée ma mére...Galimard/Julliard, 1973.

${ }^{17}$ Duby, Georges, Les procées de Jeanne D’Arc, Paris, Galiimard, 1973.

${ }^{18}$ Davis, David Brion, "Some recent directions in American Cultural History", AHR 73, fevereiro 1968, 696 et passim.

${ }^{19}$ Ver sobre o assunto Esprit 184 (aout-septembre 1992). Dossier "Quand l'historien se fait biographe": 25-59.

${ }^{20}$ Comment on écrit l'histoire, Essai d'epistemologie, Paris, Seuil, 1971.

${ }^{21}$ Ambas traduzidas no Brasil pela Editora Nova Fronteira e publicadas respectivamente em 1951 e 1968.

${ }^{22}$ Sobre o tema ver Andrée Lévesque Réflexion sur la biographie historique em l'an 2000, Revue d'histoire de l'Amérique française, vol. 54, no1, 2000, p. 95-102.

${ }^{23}$ L. Stone, "Retour au récit ou refléxions sur une nouvelle vieille histoire”, Le Débat, no40, 1980, p. 118-142.

${ }^{24}$ Sobre Braudel e as referências marxistas e estruturalistas ver E.Le Roy Ladurie, Le territoire de l'histoiren, Paris, Gallimard, 1983.

${ }^{25}$ Quem discute o assunto é o filósofo Paul Ricoeur em seu Temps et Récit, tomo 1, Paris, Seuil 1983.

${ }^{26}$ P. Veyne, Comment on écrit l'histoire - Essay d'epistémologie, Paris, Seuil, 1971.

${ }^{27}$ Número de março/abril de 1988.

${ }^{28}$ M. Foucault, L'Archeologie du savoir, Paris, Galiimard, 1969.

${ }^{29}$ M. de Certeau, L'Ecriture de l'Histoire, Paris, Gallimard, 1975.

${ }^{30}$ Ver sobre o assunto Hayden White, Metahistory. The historical imagination in Nineteenth Century Europe, J. Hoopkins University Press, 1975. Narrative discourse and historical representation, J. Hopkins University Press, 1987.

${ }^{31}$ Ver de R. Chartier, Au bord de la falaise, Paris, Albin Michel, 1998.

${ }^{32}$ Recentemente François Hartog lançou seu L'évidence de l'histoire - Ce que voient lês historiens, Paris, Éditions de l'École des Hautes Études, 2005 e Nikolay Koposov, De l'imagination historique, Paris, Éditions de l'École des Hautes Études, 2009.

${ }_{33}$ Caso da revista mensal Nossa História publicada pela Editora Vera Cruz.

${ }^{34}$ Empresto de Luis Felipe Barreto a expressão extraída de seu "Literatura e história, uma relação muito suspeita", in Geometrias do Imaginário, Rio de Janeiro, RBL, 2001, p. 197-210.

${ }^{35}$ Idem, p. 204.

${ }^{36}$ P. Veyne, Comment on écrit l'histoire - Essay d'epistémologie, Paris, Seuil, 1971. 


\title{
RESUMO
}

A biografia, uma das primeiras formas de história - depois das dos deuses e de homens célebres -, retém cada vez mais a atenção dos historiadores. Todavia, a moda da biografia histórica é recente. Com efeito, até a metade do século XX, sem ser de todo abandonada, ela era vista como um gênero avelhantado, convencional e ultrapassado por uma geração devotada a abordagens quantitativas e economicistas.

Palavras-chave: biografia, história, narrativa, romance histórico, indivíduo.

\begin{abstract}
Biographies of mythological characters and heroes or simply of renown persons were primary forms of history. They are drawing nowadays a renewed interest from historians. The new fashion of biographies perceived as an approach to history is though very recent. Indeed, up to the mid fifties, even if not totally set aside, historical biographies were considered by the new breed of historians, quantitatively and econometrically oriented, as being old fashioned, conventional and "depassees".

Keywords: biography, history, narrative, historical romance, individual.
\end{abstract}

